\title{
Positive Psychological Factors of Career Development among Undergraduate Students
}

\author{
R. Ramasamy ${ }^{1}$, Dr. D.V. Nithyanandan ${ }^{2}$
}

\section{ABSTRACT}

The purpose of this study was to investigate the relationship between self-efficacy, confidence and exploration factors of career development among undergraduate students. Also, it was hypothesized that Gender, Education status, Nature of study, Type of family would make significant differences in career self-efficacy, career confidence and career exploration. The study was conducted on 194 undergraduate students by the direct administration of career selfefficacy scale, the scale of career confidence, the scale of career exploration behavior-short form and personal information form. Among them 134 were males and 60 were females. The data were subjected to Karl Pearson's product moment correlation and one way ANOVA. The result revealed significant positive relationship among self-efficacy, confidence and exploration factors of career development and significant demographic difference in these variables among the undergraduate students. Female undergraduate students were found to have more career selfefficacy, confidence, career exploration behaviors than male undergraduate students. Undergraduate students without arrears are found to have more career self-efficacy and selfconfidence than students with arrears. Career exploration behavior does not significantly differ between students without arrears and with arrears. The hosteller undergraduate students were found to have more career self-efficacy and career exploration behavior than the day scholar undergraduate students. Career confidence does not significantly differ between hostellers and day scholars. Students of nuclear family have more career self-efficacy than joint family undergraduate students. The results are interpreted based on the career development theories.

Keywords: Self-Efficacy; Confidence; Exploration Factors; Undergraduate Students

Positive psychology talks about the promotion of positive psychological strengths like self efficacy, self confident. Like other developments, the career development is also of primary importance as it requires systematic manipulation of various human potentials. If matched there

\footnotetext{
${ }^{1}$ Ph.D. (F.T)-Research Scholar, Department of Psychology, Periyar University - Salem, India

${ }^{2}$ Assistant Professor, Department of Psychology, Periyar University - Salem, India

*Responding Author

(C) 2016 I R Ramasamy, D Nithyanandan; licensee IJIP. This is an Open Access Research distributed under the terms of the Creative Commons Attribution License (http://creativecommons.org/licenses/by/2.0), which permits unrestricted use, distribution, and reproduction in any Medium, provided the original work is properly cited.
} 


\section{Positive Psychological Factors of Career Development among Undergraduate Students}

capacities would promote a good career development. In this study two of such positive psychology strengths have been explored in relation to career development.

\section{Career development:}

According to Farren et al. (2008) Career Development is the lifelong process of managing learning, work, leisure, and transitions in order to move toward a personally determined and evolving preferred future. Further they add that Career development is an organized, formalized, planned way to achieve alignment between the individual's career needs and aspirations and the organization's work-force requirements. It integrates activities of the employees and managers with the policies and procedures of the organization. It is an ongoing process linked with the organization's human resource structures rather than a one-time event.

An ideal career development process involves having a broader skill base, Making logical job transitions, Having increasing responsibility, Having a broader prospective, Making decisions easier, Earning more and Be more satisfied.

\section{Career Self-efficacy}

According to Alberta Bendura (1977) self-efficacy is the belief that one has the power to produce that effect by completing a given task or activity related to that competency. It relates to a person's perception of their ability to reach a goal. Self-efficacy is the belief that one is capable of performing in a certain manner to attain certain goals. It is the expectation that one can master a situation, and produce a positive outcome. (E.g. 1.Based on my past experience, I feel I have the necessary skills to find a good job, 2. I care about getting a good job, but I don't worry too much about it.)

The major factors that influence self-efficacy are task oriented behaviors, nurturing environment and positive cognitive factors. Hence the career self-efficacy is the belief in self about a future course of a career action. Another related phenomenon is the career confidence that deals with the certainty about the career action performed.

\section{Career Confidence}

Confidence is generally described as a state of being certain either that a hypothesis or prediction is correct or that a chosen course of action is the best or most effective. Self-confidence is having confidence in oneself and if applied in the career development perspective it would deal with the degree of certainty in choosing a career. One additional phenomenon in career confidence is decision making. Again, in turn, decision is related to planning. And planning gives chance to the establishment of independent goals; provides a standard of measurement; converts values to action; and it allows for limited resources to be committed in an orderly way. Thus career confidence is the composition of career decision making and planning. The scale used in this study to gauge career confidence. Thus, involves items that measure these variables. (E.g.1. 


\section{Positive Psychological Factors of Career Development among Undergraduate Students}

Make a plan of your goals for the next five years. 2. Select one occupation from a list of potential occupations you are considering.)

\section{Career Exploration factors}

Studies suggest that people with self-efficacy and confidence are likely to engage in more exploratory behaviors. Career exploration is a developmental stage identified by career development theorists (Super, 1990) and occurs typically during adolescence when boys and girls try out various work roles in part time work, volunteer work, or in school/community activities. Hence here career exploration is defined as an ongoing process that includes collecting information about career interests, ability and skills, values, personality and career readiness. (E.g. 1.Sought opportunities to demonstrate work skills, 2. been retrospective in thinking about my career.)

\section{Self efficacy, confidence and exploration factors as positive strengths:}

Martin Seligman a pioneer in positive psychology perspective advocated shifting the focus of psychology from "studying and trying to undo the worst in human behavior to studying and promoting the best in human behavior”(in Baumgarder \& Crothers,2009, p3). Having this plea as the impetus social science researchers started systematically investigating on positive strengths of human behavior. Such as resilience, happiness, self-regulation. Thus in this study three of such positive strengths related to the career development namely self-efficacy, confidence have been investigated.

\section{Need for the study}

In a multicultural developing society like India when individuals find successful job they are confronted with a number of challenges and problems resulting due to the lack of understanding regarding self-efficacy, confidence and exploration behavior. Therefore it is the essential to study the nature of these self-efficacies, confidence and exploration behaviors with other individual variables. The investigator attempts to concentrate on the self-efficacy, confidence and exploration among final year undergraduate students of the Salem district a backward and developing district. A proper understanding of the above mentioned variables would aid in the healthy transmission of undergraduate students in to their successful career. So the investigation related to the study variables in this research are very much needed in the present context. Thus the following hypotheses are framed

H1. Gender makes significant difference in career self-efficacy, career confidence and career exploration

H2. Education status of students makes significant difference in career self-efficacy, career confidence and career exploration

H3. Nature of study makes significant difference in Career self-efficacy, career confidence and career exploration

H4. Type of family makes significant difference in Career self-efficacy, career confidence and career exploration 


\section{METHOD}

\section{The sample}

Two colleges (A Govt. college and a private college. Both situated in the backward areas of Salem district) were approached. Initially 250 students who gave consent were administered the questionnaire for the study. But only 194 questionnaires were found complete. Thus, the sample consists of 194 undergraduate students. Sample consists of 134 males and 60 females. Researcher collected required data by the direct administration of the questionnaire.

\section{Tools}

\section{Personal data sheet}

A personal data sheet was used to collect personal data including gender, academic standing, nature of study, type of family.

\section{Career self-efficacy source scale (CSESS):}

To measure the source of career self efficacy beliefs, the career self efficacy source scale developed by Nasta (2007) was used. This scale was developed by the author based on Bandura's (1977) Anderson and Betz (2001) and Citue and Combs (2002). It is a five part scale (1) Never (2) Rarely (3) Sometimes (4) Often and (5) Very Often. The career self efficacy scale contains five subscales which are Vicarious Learning (e.g. I see other students like me get good jobs after college), Verbal Persuasion (e.g. People tell me that I should find a job easily), Emotional Arousal (e.g. I feel really great when I am doing things to find a career), Performance Accomplishments (e.g. I have done well in the past in finding jobs).

3. Career confidence scale or career decision self-efficacy scale-short form (CDMSESF)

This scale was developed by Betz, Klein and Taylor (1996). The career confidence scale measures an individual's confidence whether individuals can successfully complete a career task. This scale consists of a total of 25 questions. The responses were scored on an interval Likert-type scale, and are (1)no confidence at all, (2) very little confidence, (3)moderate confidence, (4)much confidence, and (5)complete confidence. The career confidence scale contains five subscales which are accurate self-appraisal (e.g. Accurately assess your abilities), gathering occupational information (e.g. Talk with a person already employed in a field you are interested in), goal selection (e.g. Choose a career that will fit your preferred lifestyle), making plans for the future (e.g. Make a plan of your goals for the next five years.) and problem solving (e.g. Change majors if you did not like your first choice). According to the author, the 25-item scale is a highly reliable and valid measurement (Betz et al., 1995; Betz \& Luzzo, 1996; Betz \& Taylor, 2001).

\section{Career exploration behavior survey-revised (CES-R)}

Revised version of the career exploration behavior survey- scale was developed by Stumpf et al., (1983) and it contains 3 subscales, viz., environment exploration (e.g. Investigated career possibilities), self exploration (e.g. Established career plans for the 


\section{Positive Psychological Factors of Career Development among Undergraduate Students}

future) and intended-systematic exploration (e.g. Participated in practice interviews). The career exploration behavior survey-revised consisted of a total of 28questions. The responses were scored on an interval Likert-type scale. The scales responses were 1never, 2-somewhat, 3-a moderate amount, 4-a substantial amount, 5-a great deal. Past studies have supported that the career exploration behavior survey subscales demonstrate acceptable levels of reliability and construct validity (Stumpf et al., 1983).

\section{Method of Data Collection}

The researchers personally visited the government and private colleges in Salem. Primary data were collected by conducting direct group administration of the questionnaires with the consent of the principals of the colleges as well as the informed consent of the participants.

\section{Statistical Analysis}

The data were subjected to Karl Pearson's product correlation, independent sample t-test and one way ANOVA to test the hypotheses.

\section{RESULT}

Table 1, Correlation between career self-efficacy, career confidence and career exploration behavior.

\begin{tabular}{|l|l|l|}
\hline Correlation & Career Self-Efficacy & Career Confidence \\
\hline Career Self-Efficacy & 1 & \\
\hline Career Confidence & $.578^{* *}$ & 1 \\
\hline Career Exploration Behavior & $.553^{* *}$ & $.667^{* *}$ \\
\hline
\end{tabular}

**. Correlation is significant at the 0.01 level (2-tailed).

Table 1 shows inter correlation between career self-efficacy, career confidence and career exploration behavior. This correlation matrix clearly reveals that the career self-efficacy is positively and significantly correlated with career confidence $(r=.578, \mathrm{p}<0.01)$. And Career selfefficacy is significantly and positively correlated with career exploration behavior ( $\mathrm{r}=.553$, $\mathrm{p}<0.01$ ). Again, Career confidence is significantly and positively correlated with career exploration behavior $(\mathrm{r}=.667, \mathrm{p}<0.01)$. The significant astrixes of correlation coefficient conveys that the sample size is adequate enough to establish the correlation. Hence, these direction variables are found to have a positive in terms of their relation. Further it has been established that construing these components for the understanding of career development is reliable.

The result confirms many previous studies which revealed the significant relationship between career self-efficacy beliefs and career exploration activities (Blustein, 1989; Van Ryn \&

(c) The International Journal of Indian Psychology, ISSN 2348-5396 (e)| ISSN: 2349-3429 (p) | 159 
Vinokur, 1992; Betz \& Voyten, 1997; Foltz \& Luzzo, 1998; Sterrett, 1998). Dawes et al. (2000) had stated that the basic career self-efficacy belief that one can successfully search for a job is needed for initiating the job search, obtaining employment, enduring rejection, and staying with a job once it is obtained. Similarly, Van Ryn and Vinokur (1992) found that the higher an individual's level of career self-efficacy, the more job search behaviors and positive employment outcomes will occur. Dawes et al. (2000) found further that low career self-efficacy can limit career exploration and development. Past studies support then, that career self-efficacy beliefs can in fact influence career exploration behaviors

Table 2 Career self-efficacy, career confidence, and career exploration behaviors among various groups

\begin{tabular}{|c|c|c|c|c|}
\hline Career Behaviors & \multicolumn{2}{|c|}{ Personal variables } & Mean (SD) & t -Value \\
\hline \multirow{8}{*}{ Self-Efficacy } & \multirow{2}{*}{ Gender } & Males & $67.17(11.60)$ & \multirow{2}{*}{$14.68 *$} \\
\hline & & Females & 73.87(10.42) & \\
\hline & \multirow{2}{*}{ Arrears } & without arrears & $70.78(11.46)$ & \multirow{2}{*}{$9.683^{*}$} \\
\hline & & with arrears & 65.04(11.19) & \\
\hline & \multirow{2}{*}{ Nature of study } & Day scholar & $67.94(11.52)$ & \multirow{2}{*}{$6.868 *$} \\
\hline & & Hosteller & 72.81(11.34) & \\
\hline & \multirow{2}{*}{ Type of family } & Nuclear & $70.34(11.8)$ & \multirow{2}{*}{$5.882^{*}$} \\
\hline & & Joint & $65.60(10.3)$ & \\
\hline \multirow{8}{*}{ Confidence } & \multirow{2}{*}{ Gender } & Males & 92.63(15.06) & \multirow{2}{*}{$5.76^{*}$} \\
\hline & & Females & $97.97(12.45)$ & \\
\hline & \multirow{2}{*}{ Arrears } & without arrears & 95.82(13.50) & \multirow{2}{*}{$6.096 *$} \\
\hline & & with arrears & $90.10(16.29)$ & \\
\hline & \multirow{2}{*}{ Nature of study } & Day scholar & 93.89(14.78) & \multirow{2}{*}{$0.381^{\mathrm{NS}}$} \\
\hline & & Hosteller & 95.35(13.73) & \\
\hline & \multirow{2}{*}{ Type of family } & Nuclear & $94.66(15.1)$ & \multirow{2}{*}{$0.443^{\mathrm{NS}}$} \\
\hline & & Joint & 93.02(12.2) & \\
\hline \multirow{8}{*}{$\begin{array}{l}\text { Exploration } \\
\text { Behavior }\end{array}$} & \multirow{2}{*}{ Gender } & Males & 93.65(21.67) & \multirow{2}{*}{$5.54^{*}$} \\
\hline & & Females & $101.0(16.20)$ & \\
\hline & \multirow{2}{*}{ Arrears } & without arrears & $97.47(19.19)$ & \multirow{2}{*}{$3.072^{\mathrm{NS}}$} \\
\hline & & with arrears & 91.71(23.01) & \\
\hline & \multirow{2}{*}{ Nature of study } & Day scholar & 93.77(20.90) & \multirow{2}{*}{$6.067 *$} \\
\hline & & Hosteller & $101.81(17.81)$ & \\
\hline & \multirow{2}{*}{ Type of family } & Nuclear & $95.37(20.5)$ & \multirow{2}{*}{$0.481^{\mathrm{NS}}$} \\
\hline & & Joint & $97.78(20.0)$ & \\
\hline
\end{tabular}

Note: Males=134; Females=60; without arrears =142; with arrears =52; Day scholar =142; Hosteller =52; Nuclear Family=149; Joint Family =45; * $\mathrm{p}<0.05$; NS=Not significant.

(c) The International Journal of Indian Psychology, ISSN 2348-5396 (e)| ISSN: 2349-3429 (p) | 160 


\section{Positive Psychological Factors of Career Development among Undergraduate Students}

Career self-efficacy significantly differs between male and female undergraduate students at .05 level. Female undergraduate students are higher in career self-efficacy than male undergraduate students. This indicates that female undergraduate students have more positive and negative past experiences. They may also tend to watch others' experience and how others' self-efficacy could lead to success in job search. Others' verbal encouragement or discouragement will improve female career self-efficacy. Career confidence significantly differs between male and female undergraduate students at .05 level. Female undergraduate students are found to be more confident than male undergraduate students. This indicates that female undergraduate students are able to evaluate their own strengths and weaknesses; the female students are found to search more information about job opportunity; and are more goal directed. Further female students have been identified here as to devote more time to plan for their career and also have a better problem solving capacity. Career exploration behavior also significantly differs between male and female undergraduate students at .05 level. Female undergraduate students are found to have more career exploration behavior than male undergraduate students. This indicates that career self-efficacy and career confidence are found to influence their career exploration behavior. The table shows female undergraduate students have more self-efficacy and confidence in job searching compared with male undergraduate students. The female undergraduate students are also found to have more intended-systematic exploration, environment exploration and self exploration. Hence, the hypothesis 1 has been accepted.

Besides the table reveals that career self-efficacy significantly differs between students without arrears and with arrears at .05 level. Undergraduate students without arrears are found to have more career self-efficacy than students with arrears. This indicates students without arrears may tend to have more positive and negative experience; tend to receive more verbal encouragement. Career confidence significantly differs between students without arrears and with arrears at .05 level. Students without arrears have more career self confidence than students with arrears. This indicates that students without arrears are able to evaluate exactly their strength and weakness and to receive a lot of information about the career opportunity. They are found to be perfectly selecting their goals and plan for their future career searching compared to the students with arrears. They were also found to have more problem solving skills. Career exploration behavior does not significantly differ between students without arrears and with arrears. It is indicated that having arrears does not affect career exploration behavior. Hence, the hypothesis 2 is accepted regarding Career SE and Career Confidence but rejected with reference to CE Behavior.

Day scholars and Hostellers significantly differ in their Career self-efficacy at .05 level. The hosteller undergraduate students are found to have more career self-efficacy than the day scholar undergraduate students. Career confidence does not significantly differ between hostellers and day scholars. It indicates that the nature of study was not able to affect the career confidence of the undergraduate students. Both hosteller and day scholar students tend to equally evaluate their own strength and weakness. Career exploration behavior significantly differs between hostellers 


\section{Positive Psychological Factors of Career Development among Undergraduate Students}

and day undergraduate student at .05 level. Hosteller undergraduate students are found to have more career exploration behavior than day scholars in the undergraduate college campus. The above table shows that hosteller undergraduate students have more career self-efficacy and confidence in job searching behaviour compared with day scholar undergraduate student. The Hosteller undergraduate students are found to have more behaviour related to intendedsystematic exploration, environment exploration and self exploration. Hence, the hypothesis 3 has been accepted with regard to Career SE and CE Behavior but rejected in Career Confidence. Career self-efficacy significantly differs between types of family of undergraduate students at .05 level. Undergraduate Students of nuclear family have more career self-efficacy than joint family undergraduate students. Career confidence does not significantly differ between types of family. It indicates that type of family was not able to affect career confidence of the undergraduate students. Nuclear family and joint family students are found to equally evaluate their strength and weakness. Career exploration behavior does not significantly differ between types of family. It indicates that type of family was not able to affect career exploration behavior of the undergraduate students. Further, the table has revealed that nuclear family and joint family students are found to have equal level of confidence in their job searching behaviour.

\section{CONCLUSION}

1. Female undergraduate students are higher in career self-efficacy, confidence and exploration behavior than male undergraduate students.

2. Undergraduate students without arrears are found to have more career self-efficacy and confidence than students with arrears.

3. The hosteller undergraduate students are found to have more career self-efficacy and exploration behavior than the day scholar undergraduate students.

4. Undergraduate Students of nuclear family have more career self-efficacy than joint family undergraduate students.

The results of this study have to be interpreted as well as generalized after taking the following limitations into due consideration.

1. This study depends on self-reported measures, which are susceptible to social desirability implying students may provide answers that they rather believe to be more politically correct, than indicating one's true attitudes and behaviours. Therefore, the influence of social desirability and personal perceptions must be taken into account when interpreting the results.

2. The sample consisted of undergraduate students from government and private colleges of Salem district of in Tamilnadu only. It may not be possible to generalize the results to all higher education institutions in India.

3. The wide range of Indian Higher Education Institution types, such as arts and science universities, community colleges, smaller public institutions and private institutions were not addressed in this study, therefore results cannot be applied to all types of colleges and universities. 
Positive Psychological Factors of Career Development among Undergraduate Students

\section{Acknowledgments}

The author appreciates all those who participated in the study and helped to facilitate the research process.

\section{Conflict of Interests}

The author declared no conflict of interests.

\section{REFERENCES}

Advancing business through career development by caela farren, Ph.D., Mastery Works, Inc. (2008).

Anderson, S. L., \& Betz, N. E. (2001). Sources of social self-efficacy expectations: their measurement and relation to career development. Journal of Vocational Behavior, 58, 98-117.

Atkinson, G. Jr., \& Murrell, P. H. (1988). Kolb's experiential learning theory: a meta- model for career exploration. Journal of Counseling \& Development, 66, 374-377.

Bandura A. (1997). Self-efficacy: the exercise of control. New York: W. H. Freeman.

Bandura, A. (1977). Self-efficacy: Toward a unifying theory of behavioral change. Psychological Review, 84, 191-215.

Bandura, A. (1986). Social foundations of thought and action: a social cognitive theory. Englewood Cliffs, NJ: Prentice-Hall.

Barnes, R. C. (1994). Finding meaning in unavoidable suffering. International Forum for Logo therapy, 17, 20-26.

Betz, N. E., \&Voyten, K. K. (1997). Efficacy and outcome expectations influence career exploration and decidedness. Career Development Quarterly, 46, 179-189.

Betz, N.E., Klein, K, \& Taylor, K.M. (1996). Evaluation of a short form of the career decision making self-efficacy scale. Journal of Career Assessment, 4, 47-57. (CDMSE-SF development article).

Blustein, D. L. (1989). The role of goal instability and career self-efficacy in the career selfexploration process. Journal of Vocational Behavior, 35, 194-203.

Blustein, D. L. (1992). Applying current theory and research in career exploration to practice. The Career Development Quarterly, 41, 174-184.

Citera, M. \& Combs, J. (2002, April). Predicting Sources of Self-Efficacy Using Goal Orientation. Paper presented at the annual meeting of the Society for Industrial/Organizational Psychology, Toronto, Canada.

Combs, M. \&Citera, J. (2002, June). Assessing Sources of Self-Efficacy to Predict Self- Efficacy Strength. Paper presented at the annual meeting of the American Psychological Society, New Orleans, LA.

Dawes, M. E., Horan, J. J., \& Hackett, G. (2000). Experimental evaluation of self- efficacy treatment on technical/scientific career outcomes. British Journal of Guidance \& Counseling, 28, 87-100. 


\section{Positive Psychological Factors of Career Development among Undergraduate Students}

Dufton, B. D., \& Perlman, D. (1986). The association between religiosity and the Purpose-InLife Test: Does it reflect purpose or satisfaction? Journal of Psychology and Theology, $14,42-48$.

Durlak, J. A. (1972). Relationship between individual attitudes toward life and death. Journal of Consulting and Clinical Psychology, 38, 463.

Ebersole, P., Levinson, R., \& Svensson, C. (1987). Purpose in Life Test: Parts B and C. Psychological Reports, 61, 452.

Foltz, B. M., \& Luzzo, D. A. (1998). Increasing the career decision-making self-efficacy with nontraditional college students. Journal of College Counseling, 1, 35-45.

Foltz, B. M., \& Luzzo, D. A. (1998). Increasing the career decision-making self-efficacy with nontraditional college students. Journal of College Counseling, 1, 35-45.

Frankl, V. E. (1960). Beyond self-actualization and self-expression. Journal of Existential Psychiatry, 1, 5-20.

George, D., \& Mallery, P. (2005). SPSS for Windows Step by Step. A Simple Guide and Reference 12.0 Update, Fifth Edition. Boston: Allyn and Bacon.

Hackett, G., Lent, R. W., \& Greenhaus, J. H. (1991). Advances in vocational theory and research: A 20 retrospective. Journal of Vocational Behavior, 38, 3-38.

Hutzell, R. R. (1988). A review of the Purpose in Life Test. International Forum for Logotherapy, 11, 89-101.

Jordaan, J. P. (1963). Exploratory behavior: the formation of self and occupational concepts. In: Super, D.E., Starishevsky, R., Matlin, R. \& Jordaan, J.P. (Eds), Career Development: Self-Concept Theory (pp. 42-78). New York: College Entrance Board.

Locke, E. A., Frederick, E., Lee, C., \& Bobko, P. (1984). Effect of self-efficacy, goals, and task strategies on task performance. Journal of Applied Psychology, 69, 241- 251.

Nesdale, D., \& Pinter, K. (2000). Self-efficacy and job-seeking activities in unemployed ethnic youth. Journal of Social Psychology, 140, 608-614.

Noblejas de la Flor, M. A. (1997). Meaning levels and drug-abuse therapy: An empirical study. International Forum for Logo therapy, 20, 46-51.

Seligman, M. E., Ernst, R. M., Gillham, J., Reivich, K., \& Linkins, M. (2009). Positive education: Positive psychology and classroom interventions. Oxford review of education, 35(3), 293-311.

How to cite this article: R Ramasamy, D Nithyanandan (2016), Positive Psychological Factors of Career Development among Undergraduate Students, International Journal of Indian Psychology, Volume 3, Issue 4, No. 58, ISSN 2348-5396 (e), ISSN: 2349-3429 (p), DIP: 18.01.057/20160304, ISBN: 978-1-365-24976-1

(C) The International Journal of Indian Psychology, ISSN 2348-5396 (e)| ISSN: 2349-3429 (p) | 164 